\title{
UJI TOKSISITAS DAN FITOKIMIA EKSTRAK KASAR METANOL, KLOROFORM DAN $n$-HEKSANA ALGA COKLAT SARGASSUM VULGARE DARI PANTAI KAPONG PAMEKASAN MADURA
}

\author{
Miftahul Jannah, Ahmad Hanapi, A. Ghanaim Fasya \\ Jurusan Kimia UIN Maulana Malik Ibrahim Malang
}

\begin{abstract}
Sargassum vulgare is a brown algae (Phaeophyceae) specific in Kapong beach Pamekasan Madura, suspected of secondary metabolic compound. This compound may be bioactive compounds that can be used in the medical world pharmacology. This research aims to know the toxicity level and its active compound Sargassum vulgare's.

Extraction of active compound in Sargassum vulgare done by maceration method uses methanol, chloroform, and $n$-hexane as solutions. Each extract was tested of its toxicity to shrimp larval Artemia salina $\mathrm{L}$. A. Salina mortality data analyzed by probit Minitab 16 analysis to know the $\mathrm{LC}_{50}$ value of each extract. After that, the researcher identifies the classes of active compound by reagent test and continued by KLTA.

The result of research shows that the toxicity and crude methanol extracts, chloroform and $n$-hexane test to shrimp larval $S$. Salina $\mathrm{L}$. obtains $\mathrm{LC}_{50}$ successive value at $139,098 \mathrm{ppm}, 39,6343 \mathrm{ppm}$ and $39,8759 \mathrm{ppm}$. Phytochemical test result shows that methanol extract, chloroform, and $n$-hexane is a steroid. The results were confirmed by using KLTA's best eluent. For methanol extract eluent, $n$-hexane:ethyl acetate (7:3) create 5 spots by Rf 0,075-0,875 value. Chloroform extract, $n$-hexane:acetone (7:3) create 18 spots by Rf $0,037-0,975$. Thus $n$ hexane eluent, $n$-hexane:ethyl acetate (7:3) create 8 spots by Rf $0,05-0,962$ value.
\end{abstract}

Keywords: Brown algae (Sargassum vulgare), toxicity, phytochemical test and KLTA.

\begin{abstract}
ABSTRAK
Sargassum vulgare merupakan spesies alga coklat (Phaeophyceae) yang khas dari pantai Kapong Pamekasan Madura, yang diduga memiliki senyawa-senyawa metabolit sekunder. Senyawa-senyawa tersebut kemungkinan merupakan senyawa bioaktif yang dapat digunakan dalam dunia farmakologi. Penelitian ini bertujuan untuk mengetahui tingkat toksisitas dan golongan senyawa aktif pada Sargassum vulgare.

Ekstraksi senyawa aktif Sargassum vulgare dilakukan dengan metode maserasi menggunakan pelarut metanol, kloroform dan $n$-heksana. Masing-masing ekstrak diuji toksisitasnya terhadap larva udang Artemia salina L. Data kematian A. salina dianalisis dengan analisis probit Minitab 16 untuk mengetahui nilai $\mathrm{LC}_{50}$ masing-masing ekstrak. Selanjutnya dilakukan identifikasi golongan senyawa aktif dengan uji reagen dan dilanjutkan dengan KLTA.

Hasil penelitian menunjukkan bahwa hasil uji toksisitas ekstrak metanol, kloroform dan $n$-heksana terhadap larva udang $S$. salina $\mathrm{L}$. diperoleh nilai $\mathrm{LC}_{50}$ secara berturut-turut sebesar 139,098 ppm, 39,6343 ppm dan 39,8759 ppm. Hasil uji fitokimia menunjukkan bahwa ekstrak metanol, kloroform dan $n$-heksana adalah steroid. Hasil ini diperkuat dengan KLTA menggunakan eluen terbaik, untuk ekstrak metanol eluen $n$ heksana:etil asetat (7:3) menghasilkan 5 spot dengan nilai Rf 0,075-0,875. Ekstrak kloroform eluen $n$ heksana:aseton (7:3) menghasilkan 18 spot dengan nilai Rf 0,037-0,975. Dan ekstrak $n$-heksana eluen $n$ heksana:etil asetat (7:3) menghasilkan 8 spot dengan nilai Rf 0,05-0,962.
\end{abstract}

Kata Kunci: Alga coklat (Sargassum vulgare), toksisitas, uji fitokimia dan KLTA. 


\section{PENDAHULUAN}

Pantai Indonesia memiliki potensi alga yang sangat tinggi, tercatat sedikitnya terdapat 555 jenis alga. Kelompok umumnya yaitu alga biru, alga hijau, alga merah dan alga coklat. Sargassum vulgare merupakan salah satu golongan alga coklat. Makro alga jenis ini belum dimanfaatkan dan dibudidayakan. Menurut Asmad (2012) dalam Alfiaturrahmah (2013), menurut para penduduk dan nelayan pantai Kapong Pamekasan Madura, keberadaan S. vulgare di pantai tersebut sangat melimpah. Berdasarkan informasi tersebut alga coklat $S$. vulgare perlu ditingkatkan potensinya dengan cara diteliti guna mengetahui kandungan senyawa bioaktif khususnya yang berpotensi sebagai senyawa obat.

Skrining awal untuk pengujian bahan alam dengan uji toksisitas terhadap larva udang Artemia salina L. sering digunakan untuk mengetahui senyawa aktif yang terkandung dalam ekstrak tanaman, karena relatuf murah, cepat, dan hasilnya dapat dipercaya (Ledenberg, 1992). Uji toksisitas dengan menggunakan metode Brine Shrimp Lethality Test (BSLT) dapat digunakan sebagai uji pendahuluan pada penelitian yang mengarah pada uji sitotoksik karena ada kaitannya antara uji toksisitas dengan uji sitotoksik jika harga $\mathrm{LC}_{50}$ toksisitas akut lebih kecil dari 1000 ppm (Meyer, et al., 1982).

Tujuan dari penelitian ini adalah untuk mengetahui toksisitas dan golongan senyawa yang terdapat pada ekstrak $S$. vulgare. Sehingga diharapkan dapat memberikan informasi ilmiah kepada masyarakat mengenai bioaktivitas toksisitas alga coklat jenis Sargassum vulgare, sehingga dapat dimanfaatkan di bidang farmakologi.

\section{METODE PENELITIAN Alat dan Bahan Penelitian}

Alat-alat yang digunakan dalam penelitian ini adalah hot plate, pisau, blender, oven, timbangan analitik, kaca arloji, cawan penguap, tabung reaksi, pengaduk kaca, pipet tetes, pipet ukur 5 $\mathrm{mL}$, pipet ukur $10 \mathrm{~mL}$, pipet ukur $1 \mathrm{~mL}$, pipet mikro, penjepit, gelas beaker 100 $\mathrm{mL}$, bola hisap, erlenmeyer $250 \mathrm{~mL}$, gelas ukur $100 \mathrm{~mL}$, desikator, corong kaca, corong Buchner, aluminium foil, kertas saring, labu ukur $10 \mathrm{~mL}$, plat silika $\mathrm{GF}_{254}$, lampu penerang, vacum rotary evaporator, shaker.

Bahan sampel yang digunakan dalam penelitian ini adalah alga coklat jenis (Sargassum vulgare), metanol p.a, kloroform p.a, $n$-heksana p.a, DMSO, ragi roti, air laut, etil asetat, $\mathrm{HCl} 37 \%, \mathrm{HCl} 1 \mathrm{~N}$, $\mathrm{HCl} 2 \%$, metanol $50 \%, \mathrm{H}_{2} \mathrm{SO}_{4}$ pekat, asam asetat anhidrida, aseton, $\mathrm{FeCl}_{3} 1 \%$, gelatin, pereaksi Mayer dan Dragendorff, serbuk logam $\mathrm{Mg}, \mathrm{NaCl}$, pereaksi Liberman-Burchard, aquades, air.

\section{Uji Taksonomi}

Uji taksonomi alga coklat $S$. vulgare dilakukan secara kualitatif di Laboratorium Taksonomi, Struktur dan Pengemnbangan Tumbuhan, Jurusan Biologi, Fakultas MIPA, Universitas Brawijaya.

\section{Preparasi Sampel}

Bahan yang digunakan adalah alga coklat Sargassum vulgare, dibersihkan dengan cara dicuci pada air mengalir kemudian dikeringkan dalam oven pada suhu $38{ }^{\circ} \mathrm{C}$ selama 24 jam dan dihaluskan menggunakan blender hingga halus Serbuk $S$. vulgare diayak menggunakan ayakan yang berukuran 60-100 mesh.

\section{Uji Kadar Air}

Cawan kosong dikeringkan dalam oven pada suhu $100-105{ }^{\circ} \mathrm{C}$ kemudian didinginkan dalam desikator selama \pm 15 menit. Setelah dingin berat cawan kosong ditimbang. Sampael sebanyak 5 gram dimasukkan dalam cawan dan ditimbang. Kemudian dimasukkan dalam oven pada suhu $100-105{ }^{\circ} \mathrm{C}$ selama \pm 30 menit. Setelah kering, didinginkan dalam desikator selama \pm 15 menit. Ditimbang kembali cawan berisi sampel. Kadar air dihitung berdasarkan persamaan berikut:

$$
\text { Kadar air }=\frac{(b-c)}{(b-a)} \times 100 \%
$$


Keterangan:

$\mathrm{a}=$ berat konstan cawan kosong

$\mathrm{b}=$ berat cawan + sampel sebelum dikeringkan

$\mathrm{c}=$ berat konstan cawan + sampel setelah dikeringkan

Faktor koreksi $=\frac{100}{100-\% \text { kadar air }}$

$\%$ Kadar air terkoreksi $=$ Kadar air $-\mathrm{F}_{\text {koreksi }}$

\section{Penentuan Kadar Garam}

Sampel S. vulgare dimasukkan ke dalam beaker glass kemudian ditambahkan $10 \mathrm{~mL}$ akuades dan diaduk menggunakan magnetic stirrer selama 15 menit. Ekstraksi diulangi sebanyak 6 kali. Kemudian disaring menggunakan penyaring corong buchner. Garam yang sudah terekstrak ke dalam pelarut akuades diukur kadarnya menggunakan alat salinometer.

\section{Ekstraksi Senyawa Aktif}

Serbuk S. vulgare sebanyak $100 \mathrm{~g}$ dimaserasi dengan menggunakan $300 \mathrm{~mL}$ pelarut metanol dan dilakukan pengocokan menggunakan shaker selama $3 \times 24$ jam dengan kecepatan $120 \mathrm{rpm}$ (rotation per minutes), selanjutnya disaring. Ampas yang tersisa dimaserasi kembali sampai diperoleh filtrat bening (senyawa terekstrak semua). Ampas yang diperoleh dimaserasi kembali menggunakan pelarut yang sama sebanyak 5 kali pengulangan dengan perlakuan yang sama, setelah itu dilakukan penyaringan. Kelima filtrat yang diperoleh digabung menjadi satu (Halimah, 2010). Perlakuan yang sama juga dilakukan terhadap $100 \mathrm{~g}$ sampel alga yang diekstrak menggunakan pelarut kloroform dan $n$-heksana.

Ekstrak metanol, kloroform dan $n$ heksana yang diperoleh kemudian dipekatkan menggunakan rotary evaporator, setelah itu dialiri gas $\mathrm{N}_{2}$. Ekstrak pekat ditimbang lalu dihitung rendemennya dengan persamaan:

$\%$ Rendemen $=\frac{\text { Berat ekstrak }}{\text { Berat sampel }} \times 100 \%$

\section{Uji Sitotoksik terhadap Larva Udang Artemia salina Leach}

\section{a. Penetasan Larva Udang}

Media penetasan berupa air laut yang ditempatkan di wadah bersekat dengan pencahayaan sinar lampu pijar/neon. Telur Artemia salina L. sebanyak 2,5 mg dimasukkan dalam air laut tersebut. Kemudian diaerasi dalam waktu \pm 48 jam. larva udang yang telah menetas siap digunakan sebagai hewan uji (Juniarti, 2009).

\section{b. Uji Toksisitas (Rita, et al., 2008)}

Konsentrasi masing-masing sampel dibuat konsentrasi berbeda yakni $5 \mathrm{ppm}$, 25 ppm, 50 ppm, 100 ppm, 150 ppm, 200 ppm dan 0 ppm sebagai kontrol. Ekstrak pekat metanol, kloroform dan $n$-heksana, masing-masing dibuat larutan stok 10000 ppm dengan cara ditimbang ekstrak pekat 100 mg dan dilarutkan dengan menggunakan pelarutnya sebanyak $10 \mathrm{~mL}$. selanjutnya dipipet masing-masing dari larutan stok sebanyak $5 \mu \mathrm{L}, 25 \mu \mathrm{L}, 50 \mu \mathrm{L}$, $100 \mu \mathrm{L}, 150 \mu \mathrm{L}$ dan $200 \mu \mathrm{L}$. Kemudian dimasukkan kedalam gelas vial, dan pelarutnya diuapkan hingga kering. Kemudian ditambahkan $100 \mu \mathrm{L}$ dimetil sulfoksida (DMSO), setetes larutan ragi roti, dan air laut sampai volumenya $10 \mathrm{~mL}$. dimasukkan 10 ekor larva udang Artemia Salina L.

Pada kontrol dibuat dengan dimasukkan $2 \mathrm{~mL}$ air laut, $100 \mu \mathrm{L}$ dimetil sulfoksida, dan 1 tetes larutan ragi roti ke dalam gelas vial, kemudian ditambahkan air laut sampai volumenya $10 \mathrm{~mL}$. dimasukkan 10 ekor larva udang Artemia Salina L. pengamatan uji toksisitas untuk mengetahui nilai $\mathrm{LC}_{50}$ dengan menghitung larva udang Artemia Salina L. yang mati setelah 24 jam dari perlakuan. Kemudian dihitung larva udang yang mati dengan rumus berikut.

$\%$ mortalitas $=\frac{\text { jumlah artemia yang mati }}{\text { jumlah artemia yang diuji }} \times 100 \%$

\section{Uji Fitokimia dengan Reagen}

Uji fitokimia kandungan golongan senyawa aktif dengan uji reagen dari ekstrak pekat metanol, kloroform dan $n$ heksana dari $S$. vulgare dilakukan terhadap uji alkaloid, flavonoid, triterpenoid, 
steroid, saponin, dan tanin (Indrayani, et al., 2006).

- Uji Alkaloid (Kristanti, et al., 2008)

Ekstrak S. vulgare dimasukkan dalam tabung reaksi, ditambah $0,5 \mathrm{~mL}$ $\mathrm{HCl} 2 \%$ dan larutan dibagi dalam dua tabung. Tabung I ditambahkan 2-3 tetes reagen Dragendorff, tabung II ditambahkan 2-3 tetes reagen Mayer. Jika tabung I terbentuk endapan jingga dan pada tabung II terbentuk endapan kekuning-kuningan, menunjukkan adanya alkaloid.

\section{- Uji Flavonoid}

Ekstrak S. vulgare dimasukkan dalam tabung reaksi kemudian dilarutkan dalam 1-2 mL metanol panas $50 \%$. Setelah itu ditambah logam $\mathrm{Mg}$ dan 4-5 tetes $\mathrm{HCl}$ pekat. Larutan berwarna merah atau jingga yang terbentuk, menunjukkan adanya flavonoid.

\section{- Uji Triterpenoid dan Steroid} (Kristanti, et al., 2008)

Ekstrak S. vulgare dimasukkan dalam tabung reaksi, dilarutkan dalam 0,5 $\mathrm{mL}$ kloroform, lalu ditambah dengan $0,5 \mathrm{~mL}$ asam asetat anhidrat. Campuran ini selanjutnya ditambah dengan 1-2 $\mathrm{mL} \mathrm{H}_{2} \mathrm{SO}_{4}$ pekat melalui dinding tabung tersebut. Jika hasil yang diperoleh berupa cincin kecoklatan atau violet pada perbatasan dua pelarut menunjukkan adanya triterpenoid, sedangkan jika terbentuk warna hijau kebiruan menunjukkan adanya steroid.

\section{- Uji Saponin (Harborne, 1987)}

Ekstrak $S$. vulgare dimasukkan dalam tabung reaksi ditambah air (1:1) sambil dikocok selama 1 menit, apabila menimbulkan busa ditambahkan $\mathrm{HCl} 1$ $\mathrm{N}$, busa yang terbentuk dapat bertahan selama 10 menit dengan ketinggian 1-3 $\mathrm{cm}$, maka ekstrak positif mengandung saponin.

\section{- Uji Tanin}

Uji dengan $\mathrm{FeCl}_{3}$

Ekstrak $S$. vulgare ditambahkan dengan 3 tetes larutan $\mathrm{FeCl}_{3} 1 \%$. Jika larutan menghasilkan warna hijau kehitaman atau biru tinta, maka mengandung tanin.

\section{Uji dengan Larutan Gelatin}

Ekstrak S. vulgare sebanyak $2 \mathrm{mg}$ dimasukkan dalam tabung reaksi ditambah dengan larutan gelatin. Jika terbentuk endapan putih, menunjukkan adanya tanin

\section{Uji Fitokimia dengan KLTA}

Pemeriksaan adanya kandungan senyawa metabolit sekunder secara kualitatif pada ekstrak $S$. vulgare, dilakukan dengan metode Kromatografi Lapis Tipis Analitik (KITA) terhadap senyawa yang positif dari hasil uji reagen.

\section{Analisis Data}

Data yang diperoleh dibuat dalam bentuk tabel dan grafik, kemudian dideskripsikan hasilnya. Tingkat toksisitas larva udang Artemia salina Leach dapat diketahui dengan melakukan uji $\mathrm{LC}_{50}$ menggunakan analisis probit pada program MINITAB 16 dengan tingkat kepercayaan $95 \%$.

\section{HASIL DAN PEMBAHASAN Uji Taksonomi}

Hasil uji taksonomi menunjukkan bahwa makroalga yang digunakan dalam penelitian ini memiliki ciri-ciri yaitu bentuk agak gepeng, licin, batang utama silindris, percabangan selang-seling, mempunyai kantong udara, dan daunnya memanjang lurus pinggirnya bergelombang. Berdasarkan ciri-ciri tersebut dapat disimpulkan bahwa sampel memiliki ciri-ciri yang sama dengan alga coklat jenis Sargassum vulgare Tjondronegoro, et al., (1989).

\section{Preparasi Sampel}

Alga coklat $S$. vulgare dicuci hingga bersih untuk menghilangkan pasir maupun lumpur yang menempel pada tallusnya, kemudian dikeringkan dengan cara dioven pada suhu $38{ }^{\circ} \mathrm{C}$. Pengeringan dimaksudkan untuk mengurangi kadar air, dan mencegah tumbuhnya jamur sehingga dapat disimpan lebih lama.

$S$. vulgare yang sudah kering dihaluskan dengan menggunakan blender 
dan diayak untuk memperluas permukaan bahan sehingga mempermudah pada tahap ekstraksi, interaksi antara pelarut dengan sampel yang diekstraksi menjadi lebih efektif dan hasil ekstrak yang diperoleh maksimal (Sembiring, dkk., 2006). Dari 5 $\mathrm{Kg}$ sampel basah $S$. vulgare diperoleh serbuk kering $S$. vulgare sebanyak 400 gram.

\section{Analisis Kadar Air}

Analisis kadar air dilakukan untuk mengetahui persentase kandungan air yang terdapat di dalam sampel. Hasil persentase kadar $S$. vulgare pada Tabel 1 berikut:

Tabel 1 Hasil persentase kadar $S$. vulgare

\begin{tabular}{c|c|c}
\hline $\begin{array}{c}\text { Alga Coklat } \\
\text { (Sargassum } \\
\text { vulgare) }\end{array}$ & $\begin{array}{c}\text { Kadar Air } \\
\%\end{array}$ & $\begin{array}{c}\text { Kadar Air } \\
\text { Terkoreksi } \\
\text { \% }\end{array}$ \\
\hline Sampel basah & 83,7970 & 77,6254 \\
\hline Sampel kering & 10,4697 & 9,3528 \\
\hline
\end{tabular}

Kadar air pada $S$. vulgare basah sebesar 77,6254 \%. Astwan, et al., (2001) menyatakan bahwa kandungan air rumput laut segar berkisar 80-90 \% dan setelah pengeringan menjadi $10-20 \%$. Sedangkan kadar air $S$. vulgare kering sebesar 9,3528 $\%$. Menurut Winarno (2002) kadar air yang baik adalah kurang dari $10 \%$, karena pada tingkat kadar air tersebut waktu simpan sampel akan relatif lebih lama dan terhindar dari pencemaran yang disebabkan mikroba. Oleh karena itu, $S$. vulgare kering yang dihasilkan dapat dilakukan penyimpanan dalam selang waktu yang cukup lama.

\section{Analisis Kadar Garam}

Analisis kadar garam dilakukan untuk mengetahui kadar garam yang terdapat pada sampel. Hasil uji kadar garam S. vulgare, pada penelitian ini sebesar 15,6 ppt. Menurut Pitoyo (2004) Artemia salina akan menetas dalam waktu 24-36 jam pada salinitas 15-35 ppt. Matthew (1982) yang menyatakan bahwa paparan salinitas antara 22,7 dan $33 \mathrm{ppt}$ ada pengaruh meski tidak signifikan pada sampel mikroalga terhadap perkembangan embrio normal. Sehingga dari kedua pernyataan tersebut dapat dikatakan bahwa kadar garam pada sampel tidak mempengaruhi tingkat kematian pada larva udang Artemia salina L.

\section{Ekstraksi Maserasi}

Proses ekstraksi maserasi dilakukan dengan menggunakan variasi pelarut (metanol, kloroform dan $n$-heksana). Untuk memperoleh senyawa metabolit sekunder sesuai dengan kepolarannya. Hasil rendemen dari masing-masing ekstrak ditunjukkan pada Tabel 2 berikut:

Tabel 2 Hasil rendemen dari masingmasing ekstrak

\begin{tabular}{c|c|c}
\hline Pelarut & $\begin{array}{c}\text { Warna } \\
\text { Ekstrak Pekat }\end{array}$ & $\begin{array}{c}\text { Rendemen } \\
(\%)(\mathbf{b} / \mathbf{b})\end{array}$ \\
\hline Metanol & $\begin{array}{c}\text { Hijau Pekat } \\
\text { Kehitaman }\end{array}$ & 3,39 \\
\hline Kloroform & $\begin{array}{c}\text { Hijau Pekat } \\
\text { Kehitaman }\end{array}$ & 1,1596 \\
\hline$n$-Heksana & Hijau Pekat & 0,4228 \\
\hline
\end{tabular}

Nilai rendemen ekstrak metanol lebih besar dari kloroform dan $n$-Heksana, hal ini kemungkinkan disebabkan karena pada $S$. vulgare banyak mengandung senyawa polar, selain itu diduga senyawa yang terkandung di dalam ekstrak $S$. vulgare masih berbentuk glikosida, sehingga akan lebih larut ke dalam pelarut polar. Keberadaan senyawa-senyawa yang masih berbentuk glikosida sangat mempengaruhi jumlah rendemen hasil ekstraksi, karena umumnya senyawa metabolit sekunder yang terikat pada gula akan terekstrak pada pelarut polar.

\section{Uji Toksisitas Ekstrak $S$. vulgare dengan Larva Udang A. salina Leach}

Hasil pengamatan mortalitas Artemia salina L. dalam uji toksisitas dengan menggunakan metode BSLT diperoleh presentase mortalitas hewan uji dari masing-masing konsentrasi ekstrak yang diujikan. Berdasarkan data tersebut dilakukan perhitungan dan analisa probit dengan program Minitab 16 dilakukan untuk mengkalkulasi rataan pola mortalitas 
dan konsentrasi untuk mendapatkan nilai $\mathrm{LC}_{50}$ secara statistika dengan tingkat kepercayaan $95 \%$. kurva mortalitas larva udang Artemia salina L. terhadap masingmasing ekstrak akar rumput bambu ditunjukkan pada Gambar 1, 2 dan 3.berikut.

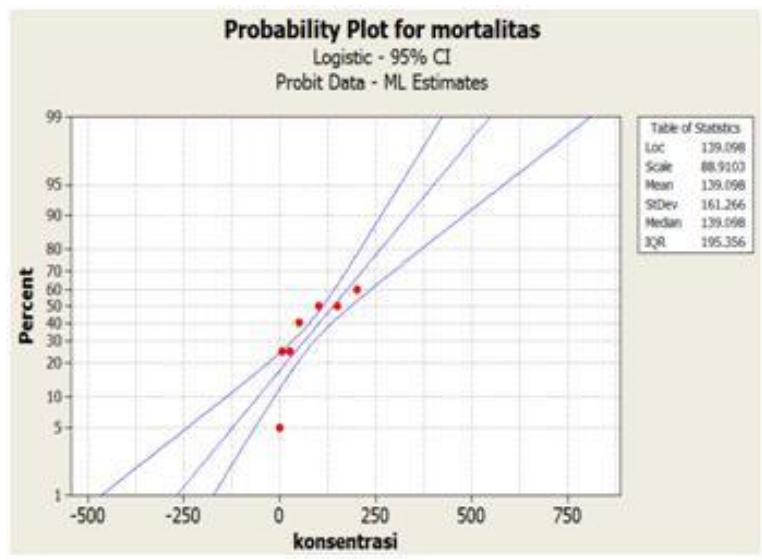

Gambar 1. Grafik Uji Toksisitas $\left(\mathrm{LC}_{50}\right)$ Ekstrak Metanol

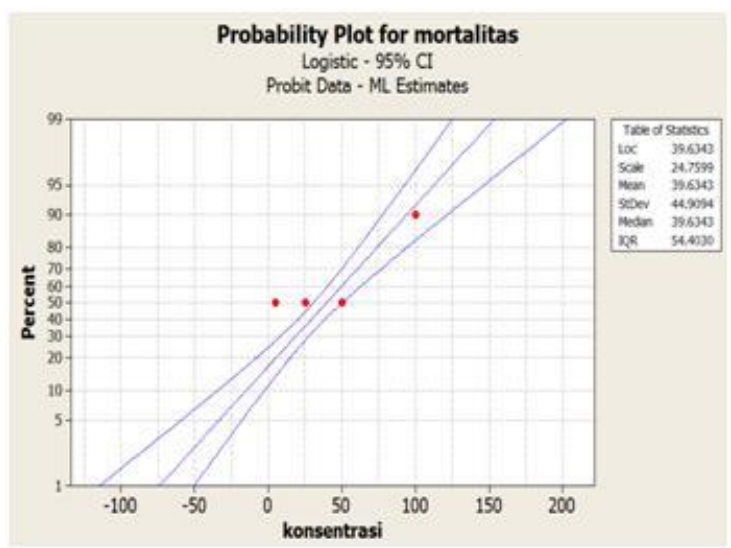

Gambar 2. Grafik Uji Toksisitas $\left(\mathrm{LC}_{50}\right)$ Ekstrak kloroform

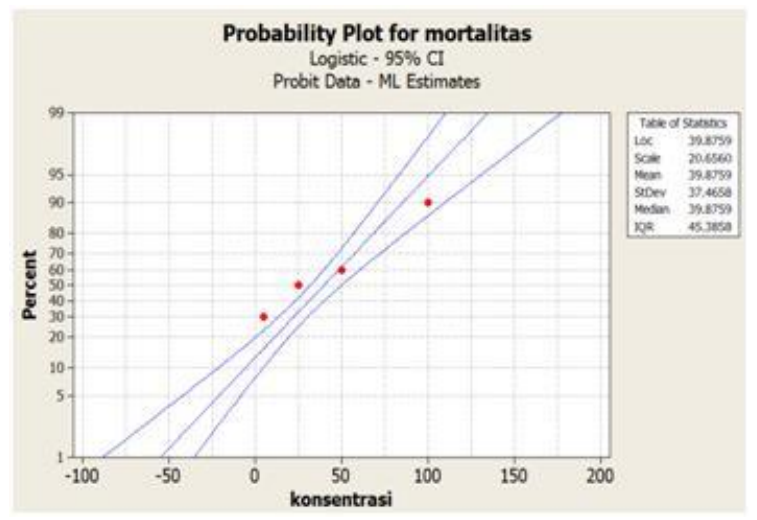

Gambar 3. Grafik Uji Toksisitas $\left(\mathrm{LC}_{50}\right)$ Ekstrak $n$-Heksana
Berdasarkan kurva mortalitas masing-masing ekstrak pelarut, diperoleh nilai $\mathrm{LC}_{50}$ sebagaimana pada tabel berikut:

Tabel 3 Nilai $\mathrm{LC}_{50}$ pada berbagai pelarut

\begin{tabular}{|c|c|}
\hline Ekstrak & LC $_{\mathbf{5 0}}(\mathbf{p p m})$ \\
\hline Metanol & 139,098 \\
\hline Kloroform & 39,6343 \\
\hline $\boldsymbol{n}$-Heksana & 39,8759 \\
\hline
\end{tabular}

Mayer, et al., (1982) menyatakan bahwa suatu ekstrak menunjukkan aktivitas ketoksikan, jika ekstrak dapat menyebabkan kematian $50 \%$ hewan uji pada konsentrasi kurang dari 1000 ppm. Dari pernyataan tersebut dapat diketahui bahwa ekstrak metanol, kloroform dan $n$ heksasna $S$. vulgare bersifat toksik terhadap larva udang $A$. salina $\mathrm{L}$. karena memiliki nilai $\mathrm{LC}_{50}<1000$ ppm.

\section{Identifikasi Golongan Senyawa Aktif}

Uji fitokimia dilakukan untuk mengetahui kandungan metabolit sekunder suatu sampel. Hasil kandungan senyawa metabolit sekunder pada ekstrak metanol, kloroform dan $n$-heksana $S$. vulgare adalah steroid. Ditunjukkan pada Tabel berikut:

Tabel 4. Hasil kandungan senyawa metabolit sekunder pada ekstrak metanol, kloroform dan $n$ heksana $S$. vulgare adalah steroid

\begin{tabular}{|l|l|l|l|}
\hline \multirow{2}{*}{$\begin{array}{l}\text { Golongan } \\
\text { senyawa } \\
\text { aktif }\end{array}$} & \multicolumn{2}{|l}{$\begin{array}{l}\text { Hasil uji reagen pada masing- } \\
\text { masing ekstrak }\end{array}$} \\
\cline { 2 - 4 } & Metanol & Kloroform & $n$-Heksana \\
\hline Alkaloid & - & - & - \\
\hline Flavonoid & - & - & - \\
\hline Saponin & - & - & - \\
\hline Tanin & - & - & - \\
\hline Steroid & +++ & +++ & +++ \\
\hline Triterpenoid & - & - & - \\
\hline
\end{tabular}

Keterangan:

+++ =kandungan senyawa lebih banyak (warna sangat pekat)

$++\quad=$ =mengandung senyawa (warna cukup pekat)

$+\quad=$ =mengandung senyawa (sedikit berwarna) =tidak mengandung senyawa 
Pemisahan

Senyawa

dengan

Menggunakan Kromatografi Lapis Tipis (KLT)

Hasil identifikasi golongan senyawa steroid menggunakan KLT pada ekstrak metanol $S$. vulgare dengan menggunakan eluen n-heksana:etil asetat (7:3) ditunjukkan sebagaimana pada Gambar 4 dan Tabel 5. Penelitian sebelumnya penelitian Handayani, dkk (2008) golongan senyawa steroid hasil KLT setelah disemprot dengan reagen Liberman-Burchard dengan terbentuknya bercak noda hijau. Menurut Syamsudin (2007) golongan senyawa steroid setelah disemprot dengan reagen LB dan diamati pada sinar UV $\lambda_{366}$ menghasilkan warna biru, ungu sampai coklat.
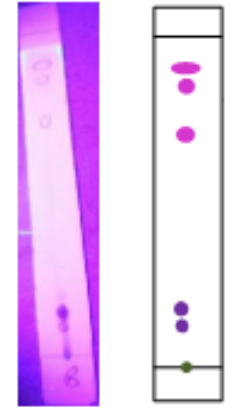

a b

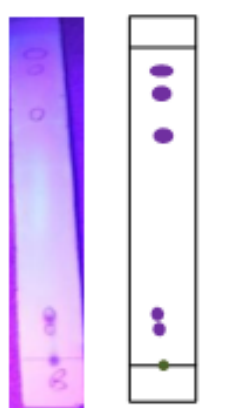

Gambar 4 Hasil KLT senyawa steroid $n$ heksana:etil asetat $(7: 3)$

Keterangan:

a. Hasil pengamatan dengan lampu UV $366 \mathrm{~nm}$ sebelum disemprot reagen Liberman-Burchard

b. Hasil pengamatan dengan UV $366 \mathrm{~nm}$ setelah disemprot reagen Liberman-Burchard

Tabel 5. Data penampakan noda senyawa steroid dari KLTA ekstrak metanol $S$. vulgare pada eluen terbaik $n$-Heksana:Etil Asetat $(7: 3)$

\begin{tabular}{|c|c|c|c|}
\hline \multirow{2}{*}{ Rf } & \multicolumn{2}{|c|}{$\begin{array}{c}\text { Warna noda dibawah } \\
\text { sinar UV pada } \lambda \mathbf{3 6 6} \mathbf{~ n m}\end{array}$} & \multirow{2}{*}{$\begin{array}{c}\text { Dugaan } \\
\text { senyawa }\end{array}$} \\
\cline { 2 - 3 } & $\begin{array}{c}\text { Sebelum } \\
\text { disemprot } \\
\text { LB }\end{array}$ & $\begin{array}{c}\text { Setelah } \\
\text { disemprot } \\
\text { LB }\end{array}$ & \\
\hline 0,075 & Ungu & Ungu & Steroid \\
\hline 0,112 & Ungu & Ungu & Steroid \\
\hline 0,675 & Merah muda & Ungu & Steroid \\
\hline 0,825 & Merah muda & Ungu & Steroid \\
\hline 0,875 & Merah muda & Ungu & Steroid \\
\hline
\end{tabular}

Hasil pemisahan golongan senyawa aktif steroid dari ekstrak $S$. vulgare kloroform dengan menggunakan eluen $n$ Heksana:Aseton (7:3) menunjukkan pemisahan yang terbaik, sebagaimana pada Gambar 5 dan Tabel 6. Menurut Syamsudin (2007) yang menyatakan bahwa eluen $n$-Heksana:Aseton (7:3) merupakan eluen yang baik dalam memisahkan senyawa steroid yang menghasilkan warna biru, ungu sampai coklat, setelah disemprot dengan reagen LB dan diamati pada sinar UV $\lambda_{366}$ yang diduga merupakan golongan senyawa steroid. Hayati (2012) senyawa steroid setelah disemprot LB terbentuk bercak noda ungu, merah muda dan hijau.

Tabel 6. Data penampakan noda senyawa steroid dari KLTA ekstrak kloroform $S$. vulgare pada eluen terbaik $n$-Heksana:Aseton (7:3).

\begin{tabular}{|c|c|c|c|}
\hline \multirow{2}{*}{ Rf } & \multicolumn{2}{|c|}{$\begin{array}{c}\text { Warna noda dibawah sinar } \\
\text { UV pada } \lambda \text { 366 nm }\end{array}$} & \multirow{2}{*}{$\begin{array}{c}\text { Dugaan } \\
\text { senyawa }\end{array}$} \\
\cline { 2 - 3 } & $\begin{array}{c}\text { Sebelum } \\
\text { disemprot } \\
\text { LB }\end{array}$ & $\begin{array}{c}\text { setelah } \\
\text { disemprot LB }\end{array}$ & \\
\hline 0,037 & Merah muda & Merah muda & Steroid \\
\hline 0,125 & Merah muda & Merah muda & Steroid \\
\hline 0,162 & Merah muda & Ungu & Steroid \\
\hline 0,2 & Ungu & Hitam & - \\
\hline 0,237 & Merah muda & Merah muda & Steroid \\
\hline 0,262 & Merah muda & Ungu & Steroid \\
\hline 0,3 & Merah muda & Ungu & Steroid \\
\hline 0,325 & Merah muda & Ungu & Steroid \\
\hline 0,362 & Ungu & Merah muda & Steroid \\
\hline 0,412 & Merah muda & Ungu & Steroid \\
\hline 0,437 & Merah muda & Ungu & Steroid \\
\hline 0,537 & Merah muda & Merah muda & Steroid \\
\hline 0,662 & $\begin{array}{c}\text { Merah muda } \\
\text { tengah hitam }\end{array}$ & $\begin{array}{c}\text { Merah muda } \\
\text { tengah merah }\end{array}$ & Steroid \\
\hline 0,725 & $\begin{array}{c}\text { Merah muda } \\
\text { tengah hitam }\end{array}$ & Ungu & Steroid \\
\hline 0,787 & Merah muda & Ungu & Steroid \\
\hline 0,9 & Merah muda & Ungu & Steroid \\
\hline 0,925 & ungu & Ungu & Steroid \\
\hline 0,975 & $\begin{array}{c}\text { Orange } \\
\text { muda }\end{array}$ & Ungu & Steroid \\
\hline
\end{tabular}



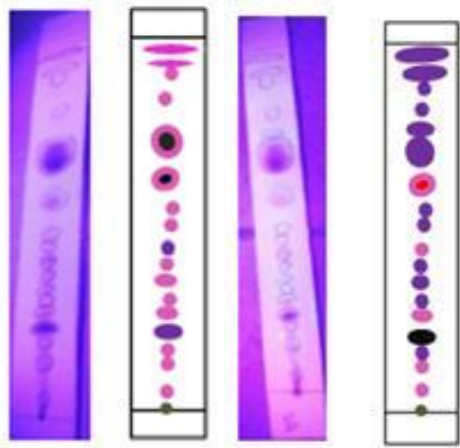

Gambar 5 Hasil KLT senyawa steroid $n$ heksana:aseton $(7: 3)$

Hasil pemisahan golongan senyawa aktif steroid dari ekstrak $S$. vulgare $n$ heksana dengan menggunakan eluen $n$ Heksana:Etil Asetat (7:3) menunjukkan pemisahan yang terbaik, sebagaimana pada Gambar 6 dan Tabel 7. Pada penelitian Handayani, dkk (2008) golongan senyawa steroid hasil KLT setelah disemprot dengan reagen Liberman-Burchard dengan terbentuknya bercak noda hijau. Hayati (2012) senyawa steroid setelah disemprot LB terbentuk bercak noda ungu, merah muda dan hijau. Menurut Syamsudin (2007) golongan senyawa steroid setelah disemprot dengan reagen LB dan diamati pada sinar UV $\lambda_{366}$ menghasilkan warna biru, ungu sampai coklat.
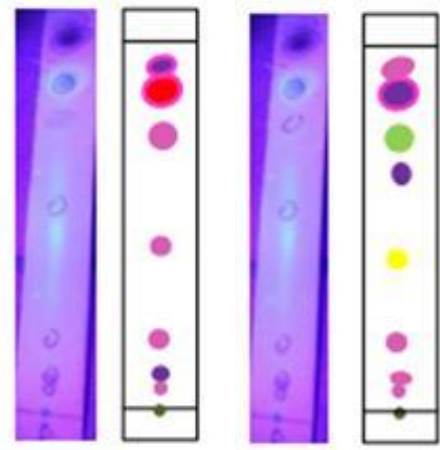

Gambar 5 Hasil KLT senyawa steroid $n$-heksana:aseton $(7: 3)$
Tabel 7. Data penampakan noda senyawa steroid dari KLTA ekstrak nheksana $S$. vulgare pada eluen terbaik $n$-Heksana:Etil Asetat (7:3).

\begin{tabular}{|c|c|c|c|}
\hline \multirow{2}{*}{$\mathbf{R f}$} & \multicolumn{2}{|c|}{$\begin{array}{r}\text { Warna noda dibawah sinar } \\
\text { UV pada } \lambda 366 \mathrm{~nm}\end{array}$} & \multirow{2}{*}{$\begin{array}{r}\text { Dugaan } \\
\text { senyawa }\end{array}$} \\
\hline & $\begin{array}{r}\begin{array}{r}\text { Sebelum } \\
\text { disemprot LB }\end{array} \\
\end{array}$ & $\begin{array}{r}\text { Setelah disemprot } \\
\text { LB }\end{array}$ & \\
\hline 0,05 & $\begin{array}{r}\text { Merah } \\
\text { muda }\end{array}$ & Merah muda & Steroid \\
\hline 0,075 & Ungu & Merah muda & Steroid \\
\hline 0,162 & $\begin{array}{r}\text { Merah } \\
\text { muda }\end{array}$ & Merah muda & Steroid \\
\hline 0,462 & $\begin{array}{r}\text { Merah } \\
\text { muda }\end{array}$ & Kuning & - \\
\hline 0,687 & - & Ungu & Steroid \\
\hline 0,787 & $\begin{array}{r}\text { Merah } \\
\text { muda }\end{array}$ & Hijau & Steroid \\
\hline 0,912 & $\begin{array}{r}\text { Merah } \\
\text { muda } \\
\text { tengan } \\
\text { merah }\end{array}$ & $\begin{array}{l}\text { Merah muda } \\
\text { tengah ungu }\end{array}$ & Steroid \\
\hline 0,962 & $\begin{array}{r}\text { Merah } \\
\text { muda } \\
\text { tangah ungu }\end{array}$ & Merah muda & Steroid \\
\hline
\end{tabular}

\section{PENUTUP \\ Kesimpulan}

1. Berdasarkan hasil uji toksisitas Ekstrak metanol, kloroform dan $n$-heksana Sargassum vulgare diperoleh nilai $\mathrm{LC}_{50}$ dari ekstrak metanol, kloroform dan $n$-heksana $S$. vulgare secara berturut tutur sebesar 139,098 ppm, 39,6343 ppm dan 39,8759 ppm.

2. Hasil uji fitokimia menunjukkan bahwa ekstrak metanol, kloroform dan $n$ heksana $S$. vulgare mengandung senyawa golongan steroid. Hasil pemisahan KLTA untuk ekstrak metanol eluen $n$-heksana:etil asetat (7:3) menghasilkan 5 spot. Ekstrak kloroform eluen $n$-heksana:aseton (7:3) menghasilkan 18 spot. Dan ekstrak $n$ heksana eluen $n$-heksana:etil asetat (7:3) menghasilkan 8 spot.

\section{Saran}

Diperlukan pemisahan lebih lanjut untuk memisahkan senyawa aktif dengan Kromatografi kolom. Hasil isolat diidentifikasi dengan instrumen LC-MS 
V. DAFTAR PUSTAKA

Alfiaturrahmah. 2012. Uji Aktivitas Antibakteri Ekstrak Kasar Etanol, Kloroform dan $n$-heksana Alga Coklat Sargassum vulgare Asal Pantai Kapong Pamekasan. Skripsi Tidak Diterbitkan. Malang: Fakultas Sains dan Teknologi UIN malang.

Asmad. 2012. Wawancara komunikasi. Kelimpahan alga coklat jenis Sargassum vulgare di Pantai Kapong Kabupaten Pamekasan. 17 Maret 2012.

Astawan, M., Muchtadi, D., Tutik, W., 2001.Pemanfaatan Rumput Laut pada Berbagai Makanan Jajanan Untuk Mencegah Timbulnya Defisiensi Iodium dan Penyakit Degeneratif. LaporanPenelitian. Bogor: IPB.

Halimah, N. 2010. Uji Fitokimia dan Uji Toksisitas Ekstrak Tanaman Anting-anting (Acalypha indica L.) Terhadap Larva Udang ( Artemia Salina Leach). Skripsi Tidak Diterbitkan. Malang: Jurusan Kimia Universitas Islam Negeri Maulana Malik Ibrahim.

Handayani, D., Sayuti, N. dan Dachriyanus. 2008. Isolasi dan Karakterisasi Senyawa Antibakteri Epidioksi Sterol dari Spon Laut Petrosia nigrans, Asal Sumatera Barat. Prosiding Seminar Nasional Sains dan Teknologi-II 2008. Lampung: Universitas Lampung.

Harborne. J.B. 1987. Metode Fitokimia Penuntun Cara Modern Menganalisis Tumbuhan. Diterjemahkan oleh Kokasih Padmawinta dan Iwang Soediro. Bandung. Penerbit ITB.

Hayati, E.K., Jannah, A., dan Ningsih, R. 2012. Identifikasi Senyawa Dan Aktivitas Antimalaria In Vivo Ekstrak Etil Asetat Tanaman Anting-Anting (Acalypha Indica L.). molekul, Vol. 7. N0.1. hal:2032.
Juniarti. 2009. Kandungan Senyawa Kimia, Uji Toksisitas (Brine Shrimp Lethality Test) dan Antioksidan (1,1-diphenyl-2pikrilhydrazyl) dari Ekstrak Daun Saga (Abrus precatorius L.). Jurnal Kimia Fakultas Kedokteran Universitas YARSI Jakarta. Vol 13, No 1: 50-54.

Kristanti, A.N., Aminah, N.S., Tanjung, M. dan Kurniadi, B. 2008. Buku Ajar Fitokimia. Surabaya: Airlangga University Press.

Ledenberg, J. 1992. Encylopedi of Microbiology, Volume Academic Press Inc, Rockefller University, New York.

Matthew P. Coglianese. 1982. The Effects of Salinity on Copper and Silver Toxicity to Embryos of the Pacific Oyster. California Department of Fish and Game, Marine Bioassay Laboratory, 2201 Garden Road, Monterey, California.

Meyer, B.N., Fergini, N.R., Putnam, J.E., Jacobsen, L.B., Nicholas, D.E. dan Mc Laughin, J.L. 1982. Brine Shrimp; a Convient General Bioassay for Active Plant Constituents. Plant Medica.

Pitoyo, Ahmad. 2004. perikanannusantara.blogspot.com/artemia.ht ml diakses pada Maret 2014.

Rita,W.S., Suirta, I.W. dan Sabirin, A. 2008. Isolasi dan Identifikasi Senyawa yang Berpotensi Sebagai Antitumor pada Daging Buah Pare (Momordica carantia L). Jurnal Jurusan Kimia FMIPA Universitas Udayana 2(1), ISSN 1907-9850: 16.

Syamsudin, Tjokrosonto, S., Wahyuno, S dan Mustofa. 2007. Aktivitas Antiplasmodium dari dua fraksi Ekstrak n-heksana Kulit Batang Asam Kandis (Gracinia parvifoli Miq).Majalah Farmasi indonesia, 18 (4), 210-215. 
Tjondronegoro dan Dewi, P. 1989. Botani Umum II. Bogor: Pusat Antar Universitas IPB.

Winarno, F.G. 2002. Kimia Pangan dan

Gizi. Jakarta: gramedia Pustaka Utama. 